\title{
Effect of Replant Disease on Growth of Malus x domestica 'Ligol' Cultivated on P-series Apple Rootstocks
}

\author{
Edward Żurawicz ${ }^{1}$, Kris Pruski, $^{2}$ Mariusz Lewandowski ${ }^{1} \&$ Marek Szymajda ${ }^{1}$ \\ ${ }^{1}$ Research Institute of Horticulture, Skierniewice, Poland \\ ${ }^{2}$ Department of Plant \& Animal Sciences, Dalhousie University, Truro, Canada \\ Correspondence: Edward Żurawicz, Research Institute of Horticulture, Konstytucji 3 Maja 1/3, 96-100 \\ Skierniewice, Poland. Tel: 48-46-834-54-25. E-mail: Edward.Zurawicz@inhort.pl
}

Received: July 18, 2013 Accepted: August 20, 2013 Online Published: September 15, 2013

doi:10.5539/jas.v5n10p28 URL: http://dx.doi.org/10.5539/jas.v5n10p28

\begin{abstract}
The study was conducted in 2009 and repeated in 2010. Its aim was to determine the effect of replant disease on the growth vigour of Malus $x$ domestica 'Ligol' grafted on P-series rootstocks (P 2, P 14, P 16, P 22, P 59, P 60, P 66, P 67 and P 68) and rootstocks M.7, M.9, M.26, MM.106, CG 16. Plant material for the study was produced by winter grafting the scions of 'Ligol' on the above rootstocks. In mid-April, mineral soil was collected from a field where for the previous 25 years an apple orchard had been cultivated. The soil was collected from two soil layers: the arable layer $(0-20 \mathrm{~cm})$ and the sub-arable layer $(20-40 \mathrm{~cm})$, and mixed at a ratio of 1:1 by volume. The mixed soil was divided into two parts: one part was pasteurized with steam $\left(95^{\circ} \mathrm{C}\right.$ for 30 minutes $)$, the other part was not pasteurized. Plastic containers ( 5 litre) were filled with both types of soil and the grafts were planted. Each treatment involved 20 trees. Two weeks after planting, a slow-release fertilizer was added ( $20 \mathrm{~g}$ per container $)$ and a drip irrigation system installed. The containers were placed outdoors and the trees were grown until late October when stem height and fresh weight of the root system were recorded. Regardless of the rootstock, 'Ligol' trees in sterilized soil grew less vigorously than the trees in 'sick' soil; however, those trees produced a significantly larger root system.
\end{abstract}

Keywords: Malus $x$ domestica, apple replant disease, soil disinfection, soil sickness

\section{Introduction}

Apple replant disease (ARD), also called 'soil sickness', is a major problem in the cultivation of apple orchards in the temperate climate zone. The disease manifests itself in young trees of apple (Malus $\mathrm{x}$ domestica BORKH.) that were planted in a field where previously trees of the same species had been cultivated for a long time (Mai \& Abawi, 1981). Typical symptoms of the disease include the withering away of the root system, weakening of tree growth, and reduced yields of the newly planted trees. The factors that cause ARD are nematodes present in the soil, which destroy the root system, chemical compounds produced by decaying roots, and accumulation in the soil of bacteria and fungi harmful to the root system, as well as interaction of all these factors (Mai, Merwin, \& Abawi, 1994; Mazzola, 1998). Severe symptoms of soil fatigue occur especially when young trees are planted in the same rows in which the old trees grew (Buszard \& Jensen, 1986; Facteau, Cestnut, \& Rowe, 1996; Leinfelder \& Merwin, 2006).

Poland is a major producer of apples; apple orchards are grown over a large area, but in over $50 \%$ of these orchards apple replant disease can be found, as reported by Szczygieł \& Zepp (1998). The same authors (Szczygieł \& Zepp, 1998) report that in Poland the disease occurs more often in light soils and those of neutral or slightly acidic $\mathrm{pH}$ than in compact or acid soils. Undoubtedly the best way to avoid the problem associated with apple replant disease is to establish orchards on fresh soils that have not been used for the cultivation of apple trees. In areas with a high concentration of fruit crops this is, however, not possible. In that case, it is recommended to disinfect the soil (Vang-Petersen, 1970; Otto \& Winkler, 1993), use various agrotechnical treatments, or select appropriate rootstocks (Leinfelder \& Merwin, 2006; Laurent, Merwin, Fazio, \& Thies, 2010). 
The aim of the experiment was to investigate the sensitivity of 'Ligol' apple trees, growing on various vegetatively propagated rootstocks, to replant disease (or replant disorder) caused by long-term cultivation of an apple orchard in the same location.

\section{Methods and Materials}

The study was conducted in 2009 and 2010. It involved 'Ligol' apple trees growing on different vegetative rootstocks for apple, originating from different breeding centres and also used in fruit production in Poland. Among the rootstocks there were Polish rootstocks - P 2 (dwarf), P 14 (semi-dwarf), P 16 (dwarf), P 22 (very dwarf), P 59 (very dwarf), P 60 (semi-dwarf), P 66 (dwarf), P 67 (dwarf to semi-dwarf)), P 68 (dwarf); English rootstocks - M.7 (semi-dwarf), M.9 (dwarf), M.26 (semi-dwarf), MM.106 (vigorous); and one American rootstock CG 16 (dwarf). All of them came from the same source, had well-developed root system, and were virus-free; the diameter of the stem of the rootstocks at $10 \mathrm{~cm}$ above the root crown was $8-10 \mathrm{~mm}$. The rootstocks were dug out from stool-beds in late October 2009 and 2010, sorted out, and placed in cold storage at a temperature of $0^{\circ} \mathrm{C}$. In late March, in both years of the study, the rootstocks were grafted with scions of the cultivar 'Ligol' (winter grafting in hand), derived from virus-free mother trees. The resulting grafts were planted in early April to plastic containers, with a capacity of about $5 \mathrm{dcm}^{3}$, filled with a substrate. The substrate was the soil from an orchard in which apple trees had been grown for the previous 25 years. The soil was taken from the locations (rows) in which the old trees grew, separately from two layers: from the arable layer $(0-20 \mathrm{~cm})$ and sub-arable layer $(20-40 \mathrm{~cm})$. From both batches of soil, soil samples were taken for chemical analyses to determine soil $\mathrm{pH}$ and the levels of $\mathrm{P}$, $\mathrm{K}$ and $\mathrm{Mg}$. Then the soil from the two layers was thoroughly mixed at a ratio of 1:1 by volume and divided into two parts. One part of the soil was subjected to pasteurization (disinfection) by steaming with superheated dry steam at a temperature of $95^{\circ} \mathrm{C}$ for 30 minutes. An S-950 Special-Moeschle steamboiler was used as a source of the steam. The other part of the soil was not pasteurized and was used as the control. Five days after pasteurization, the plastic containers were filled with this soil, the grafted rootstocks were planted in them, and the containers were placed in a field covered with white agrotextile; a drip irrigation system was installed for the plants. Two weeks after planting, slow release fertilizer Osmocote was introduced to each container at $4 \mathrm{~g} / \mathrm{l}$ of substrate $(20 \mathrm{~g} /$ container). In both years of the study, the trees in the containers were grown until the end of the growing season, which was 7 months. Each experimental combination was represented by 20 trees. In 2009-2010, the following parameters of the trees were assessed:

- levels of macroelements in the leaves (\% dry weight) - September 2009 and 2010

- chlorophyll content in the leaves using a YARA N-Tester - September 2009 and 2010

- increase in $\mathrm{mm}$ of the diameter of the rootstocks at a height of $10 \mathrm{~cm}$ at the beginning of vegetation in relation to the diameter of the rootstocks at the end of vegetation

- the height of the stem of the rootstock $(\mathrm{cm})$ - at the end of vegetation

- fresh weight of the root system of the trees $(\mathrm{g})$ - at the end of vegetation.

The results of measurements, except for levels of macroelements in the leaves, were analyzed with analysis of variance; to assess the differences between means, Duncan's t-test was used at a 5\% significance level. Macroelements in the leaves were analyzed in mixed samples from 2009 and 2010 without replication.

\section{Results and Discussion}

The results of the chemical analysis of the soil used in the experiment are given in Table 1, and those concerning the height of stems, the levels of macroelements, growth vigour, as measured by the increase in the diameter and height of the stem, and the size of the root system of 'Ligol' apple trees, growing on different rootstocks in the disinfected and non-disinfected soil are presented in Tables 2, 3, 4 and 5. The $\mathrm{pH}$ of the soil in which the trees were grown was slightly acidic, and soil pasteurization slightly contributed to an increase in $\mathrm{pH}$ and in the level of $\mathrm{P}, \mathrm{K}$ and $\mathrm{Mg}$ in the soil. According to Kłossowski \& Czynczyk (1974), the pH values and the levels of P, K and Mg in the soil given in Table 1 are considered to be optimal for growing apple trees in Poland.

A comparison of the amounts of macroelements in the leaves of the trees grown in the pasteurized soil and in the 'sick' soil indicates that the leaves of the trees grown in the disinfected soil, irrespective of the rootstock, contained more of the elements tested. On average, there was 3\% more $\mathrm{K}, 5 \%$ more $\mathrm{Mg}$ and $17 \%$ more $\mathrm{P}$ and $\mathrm{Ca}$ over the two years of study (Table 2). This might have been expected because the disinfected soil was also richer in these elements. Vang-Peterson (1970), in a container experiment, also found only a slight increase in the levels of $\mathrm{N}, \mathrm{P}, \mathrm{K}$ and $\mathrm{Mg}$ in the leaves of trees growing in a soil disinfected with chloropicrin in relation to a non-disinfected soil. 
Table 1. Results of soil analysis before the experiment (Skierniewice, 2009 and 2010)

\begin{tabular}{llllll}
\hline \multirow{2}{*}{ Soil sample } & \multirow{2}{*}{$\mathrm{pH} \mathrm{KCl}^{\mathrm{z}}$} & $\mathrm{P}^{\mathrm{y}}$ & $\mathrm{K}^{\mathrm{y}}$ & $\mathrm{Mg}^{\mathrm{x}}$ & $\mathrm{K}: \mathrm{Mg}$ \\
\cline { 3 - 5 } & \multicolumn{4}{c}{$\mathrm{mg} / 100 \mathrm{~g}$ soil } & ratio \\
\hline 'Sick' soil & 6.8 & 10.8 & 11.0 & 5.70 & 1.93 \\
Disinfected soil & 6.9 & 11.1 & 12.7 & 6.17 & 2.06 \\
\hline
\end{tabular}

${ }^{\mathrm{z}}$ determined in $\mathrm{KCl}$ by electrochemical method.

${ }^{y}$ phosphorus and potassium content were determined by emission spectrometry using the Egner-Rhiem method.

${ }^{\mathrm{x}}$ magnesium content was determined by emission spectrometry using the Schachtsabel method.

Table 2. Levels of macroelements in the leaves of the leading shoots of 'Ligol' apple trees grown on different rootstocks in a 'sick' soil and pasteurized soil (Skierniewice, average for 2009 and 2010)

\begin{tabular}{lccccccccccc}
\hline & \multicolumn{4}{c}{ 'sick' soil } \\
\cline { 2 - 11 } Rootstock & $\mathrm{N}$ & $\mathrm{P}$ & $\mathrm{K}$ & $\mathrm{Mg}$ & $\mathrm{Ca}$ & $\mathrm{N}$ & $\mathrm{P}$ & $\mathrm{K}$ & $\mathrm{Mg}$ & $\mathrm{Ca}$ \\
\cline { 2 - 11 } & & \multicolumn{1}{c}{ \% dry weight } \\
\hline P 2 & $2.53^{*}$ & 0.19 & 1.51 & 0.25 & 0.72 & 2.42 & 0.21 & 1.52 & 0.23 & 0.72 \\
P 14 & 2.47 & 0.17 & 1.90 & 0.21 & 0.90 & 2.69 & 0.19 & 1.73 & 0.22 & 0.93 \\
P 16 & 2.41 & 0.20 & 1.68 & 0.20 & 0.83 & 2.87 & 0.24 & 1.65 & 0.19 & 0.91 \\
P 22 & 2.49 & 0.20 & 1.44 & 0.21 & 0.73 & 2.17 & 0.27 & 1.75 & 0.22 & 0.78 \\
P 59 & 2.37 & 0.20 & 1.77 & 0.22 & 1.04 & 2.45 & 0.27 & 1.72 & 0.23 & 0.98 \\
P 60 & 2.31 & 0.19 & 1.65 & 0.17 & 0.92 & 2.35 & 0.24 & 1.70 & 0.18 & 0.84 \\
P 66 & 2.50 & 0.17 & 1.53 & 0.17 & 0.62 & 2.19 & 0.26 & 1.56 & 0.21 & 0.90 \\
P 67 & 2.41 & 0.17 & 1.66 & 0.20 & 0.67 & 2.91 & 0.23 & 1.89 & 0.33 & 1.78 \\
P 68 & 2.34 & 0.19 & 1.46 & 0.17 & 0.62 & 2.34 & 0.18 & 1.62 & 0.13 & 0.50 \\
CG 16 & 2.32 & 0.11 & 1.54 & 0.10 & 0.55 & 2.35 & 0.12 & 1.74 & 0.17 & 0.84 \\
M.7 & 2.50 & 0.16 & 1.50 & 0.22 & 0.73 & 2.47 & 0.17 & 1.38 & 0.20 & 0.66 \\
M.9 & 2.42 & 0.16 & 1.85 & 0.18 & 0.79 & 2.60 & 0.19 & 1.66 & 0.20 & 0.96 \\
M.26 & 2.42 & 0.19 & 1.69 & 0.23 & 0.75 & 2.64 & 0.17 & 1.85 & 0.22 & 0.97 \\
MM.106 & 2.35 & 0.18 & 1.63 & 0.21 & 0.80 & 2.44 & 0.19 & 1.82 & 0.18 & 0.76 \\
\hline
\end{tabular}

*analyses were performed on a mixed sample of leaves collected in 2009 and 2010.

In both years, the type of the substrate had a large effect on the growth vigour of 'Ligol' apple trees, as measured by the increase in the diameter of the trees, their height and the weight of the root system produced. Irrespective of the rootstock, in both years, the trees growing in the non-disinfected soil had on average a much higher increase in the diameter of the stem and its height than those which were grown in the disinfected soil (Tables 3 and 4). During both years, there were very strong similarities in the results of this experiment, and poor growth of the trees in the pasteurized soil indicate that soil pasteurization resulted in a long-term loss of the physico-chemical properties essential for the growth of trees, and, above all, of biological life. Perhaps, the response of the trees grown in the pasteurized soil (disinfected with steam) would have been different if the trees had not been planted in a freshly pasteurized soil ( 5 days after pasteurization), but after a period of 2 weeks, or even later. Our results are markedly different from those presented by Mai and Abawi (1981) and Smith (1994), who found that soil fumigation prior to planting apple trees contributed to an improvement in their growth and fruiting. However, our results correspond to those obtained by Leinfelder and Mervin (2006). In these studies (years 2002 and 2003) trees (rootstocks) grown in a fumigated soil also grew less vigorously (produced thinner and shorter stems) than on non-fumigated (control) plots. The authors also cite similar (unpublished) results of observations concerning the growth and fruiting of peach and almond trees in California, and state that it may be caused by the residue of the fumigants in the soil. Leinfelder and Mervin (2006), however, did not study the size of the root system of those trees. 
Table 3. Increase in mm of the stem diameter of 'Ligol' apple trees grown on different rootstocks in a 'sick' soil and disinfected soil (Skierniewice, 2009 and 2010)

\begin{tabular}{lllllll}
\hline \multirow{2}{*}{ Rootstock } & \multicolumn{3}{c}{ 'sick' soil } & \multicolumn{3}{c}{ disinfected soil } \\
\cline { 2 - 7 } & 2009 & 2010 & mean & 2009 & 2010 & mean \\
\hline P 2 & $4.09^{\mathrm{h} *}$ & $4.25^{\mathrm{h}}$ & $4.17^{\mathrm{i}}$ & $2.06^{\mathrm{i}}$ & $2.52^{\mathrm{h}}$ & $2.29^{\mathrm{k}}$ \\
P 14 & $2.92^{\mathrm{d}}$ & $3.00^{\mathrm{c}}$ & $2.96^{\mathrm{d}}$ & $0.83^{\mathrm{e}}$ & $0.47^{\mathrm{bc}}$ & $0.65^{\mathrm{e}}$ \\
P 16 & $2.60^{\mathrm{c}}$ & $2.88^{\mathrm{b}}$ & $2.74^{\mathrm{c}}$ & $1.72^{\mathrm{g}}$ & $1.58^{\mathrm{e}}$ & $1.65^{\mathrm{g}}$ \\
P 22 & $2.89^{\mathrm{d}}$ & $3.97^{\mathrm{f}}$ & $3.43^{\mathrm{e}}$ & $2.07^{\mathrm{i}}$ & $1.77^{\mathrm{f}}$ & $1.92^{\mathrm{h}}$ \\
P 59 & $3.25^{\mathrm{e}}$ & $4.33^{\mathrm{i}}$ & $3.79^{\mathrm{g}}$ & $2.13^{\mathrm{j}}$ & $2.91^{\mathrm{i}}$ & $2.52^{1}$ \\
P 60 & $4.10^{\mathrm{h}}$ & $4.22^{\mathrm{gh}}$ & $4.16^{\mathrm{hi}}$ & $2.24^{\mathrm{k}}$ & $2.12^{\mathrm{g}}$ & $2.18^{\mathrm{j}}$ \\
P 66 & $5.37^{\mathrm{i}}$ & $6.25^{1}$ & $5.81^{\mathrm{k}}$ & $0.45^{\mathrm{b}}$ & $0.35^{\mathrm{a}}$ & $0.40^{\mathrm{b}}$ \\
P 67 & $5.89^{\mathrm{j}}$ & $5.37^{\mathrm{j}}$ & $5.63^{\mathrm{j}}$ & $0.33^{\mathrm{a}}$ & $0.37^{\mathrm{a}}$ & $0.35^{\mathrm{a}}$ \\
P 68 & $2.06^{\mathrm{b}}$ & $3.20^{\mathrm{d}}$ & $2.63^{\mathrm{b}}$ & $1.15^{\mathrm{f}}$ & $0.97^{\mathrm{d}}$ & $1.06^{\mathrm{f}}$ \\
CG 16 & $0.99^{\mathrm{a}}$ & $0.83^{\mathrm{a}}$ & $0.91^{\mathrm{a}}$ & $0.85^{\mathrm{e}}$ & $0.49^{\mathrm{c}}$ & $0.67^{\mathrm{e}}$ \\
M.7 & $3.57^{\mathrm{f}}$ & $3.71^{\mathrm{e}}$ & $3.64^{\mathrm{f}}$ & $2.02^{\mathrm{h}}$ & $2.08^{\mathrm{g}}$ & $2.05^{\mathrm{i}}$ \\
M.9 & $4.10^{\mathrm{h}}$ & $4.16^{\mathrm{g}}$ & $4.13^{\mathrm{h}}$ & $0.75^{\mathrm{d}}$ & $0.45^{\mathrm{b}}$ & $0.60^{\mathrm{d}}$ \\
M.26 & $6.08^{\mathrm{k}}$ & $5.62^{\mathrm{k}}$ & $5.85^{1}$ & $0.58^{\mathrm{c}}$ & $0.50^{\mathrm{c}}$ & $0.54^{\mathrm{c}}$ \\
MM.106 & $4.02^{\mathrm{g}}$ & $4.28^{\mathrm{hi}}$ & $4.15^{\mathrm{hi}}$ & $2.04^{\mathrm{hi}}$ & $2.48^{\mathrm{h}}$ & $2.26^{\mathrm{k}}$ \\
\hline
\end{tabular}

* means in columns marked with the same letter are not significantly different at $\mathrm{P}=0.05$.

Table 4. Height in cm of the stems of 'Ligol' apple trees grown on different rootstocks in 'sick' soil and disinfected soil (Skierniewice, 2009 and 2010)

\begin{tabular}{lllllll}
\hline \multirow{2}{*}{ Rootstock } & \multicolumn{3}{c}{ 'sick' soil } & \multicolumn{3}{c}{ disinfected soil } \\
\cline { 2 - 7 } & 2009 & 2010 & mean & 2009 & 2010 & mean \\
\hline P 2 & $67.8^{\mathrm{e} *}$ & $93.8^{\mathrm{d}}$ & $80.8^{\mathrm{de}}$ & $37.5^{\mathrm{de}}$ & $86.7^{\mathrm{j}}$ & $62.1^{\mathrm{t}}$ \\
P 14 & $67.5^{\mathrm{e}}$ & $115.1^{\mathrm{i}}$ & $91.3^{\mathrm{i}}$ & $36.6^{\mathrm{d}}$ & $37.4^{\mathrm{d}}$ & $37.0^{\mathrm{f}}$ \\
P 16 & $71.1^{\mathrm{g}}$ & $102.3^{\mathrm{f}}$ & $86.7^{\mathrm{h}}$ & $25.0^{\mathrm{a}}$ & $25.5^{\mathrm{b}}$ & $24.5^{\mathrm{a}}$ \\
P 22 & $59.5^{\mathrm{bc}}$ & $101.3^{\mathrm{f}}$ & $80.4^{\mathrm{d}}$ & $48.4^{\mathrm{g}}$ & $39.8^{\mathrm{e}}$ & $44.1^{\mathrm{g}}$ \\
P 59 & $74.3^{\mathrm{h}}$ & $86.7^{\mathrm{c}}$ & $80.5^{\mathrm{de}}$ & $65.3^{\mathrm{j}}$ & $53.7^{\mathrm{h}}$ & $59.5^{\mathrm{k}}$ \\
P 60 & $58.0^{\mathrm{b}}$ & $110.4^{\mathrm{g}}$ & $84.2^{\mathrm{g}}$ & $57.2^{\mathrm{i}}$ & $81.6^{\mathrm{i}}$ & $69.4^{\mathrm{n}}$ \\
P 66 & $60.0^{\mathrm{bc}}$ & $78.8^{\mathrm{b}}$ & $69.4^{\mathrm{b}}$ & $38.1^{\mathrm{e}}$ & $14.7^{\mathrm{a}}$ & $26.4^{\mathrm{b}}$ \\
P 67 & $63.0^{\text {cd }}$ & $99.6^{\mathrm{e}}$ & $81.3^{\mathrm{e}}$ & $53.3^{\mathrm{h}}$ & $50.9^{\mathrm{g}}$ & $52.1^{\mathrm{j}}$ \\
P 68 & $69.2^{\mathrm{f}}$ & $86.6^{\mathrm{c}}$ & $77.9^{\mathrm{c}}$ & $42.2^{\mathrm{f}}$ & $50.0^{\mathrm{g}}$ & $46.1^{\mathrm{h}}$ \\
CG 16 & $28.0^{\mathrm{a}}$ & $48.6^{\mathrm{a}}$ & $38.3^{\mathrm{a}}$ & $26.8^{\mathrm{b}}$ & $34.6^{\mathrm{c}}$ & $30.7^{\mathrm{d}}$ \\
M.7 & $75.5^{\text {hi }}$ & $128.7^{\mathrm{j}}$ & $102.1^{\mathrm{j}}$ & $48.0^{\mathrm{g}}$ & $46.2^{\mathrm{f}}$ & $47.1^{\mathrm{i}}$ \\
M.9 & $64.2^{\mathrm{d}}$ & $100.8^{\mathrm{e}}$ & $82.5^{\mathrm{f}}$ & $30.5^{\mathrm{c}}$ & $36.1^{\text {cd }}$ & $33.3^{\mathrm{e}}$ \\
M.26 & $62.0^{\mathrm{c}}$ & $113.0^{\mathrm{h}}$ & $87.5^{\mathrm{h}}$ & $29.7^{\mathrm{bc}}$ & $26.3^{\mathrm{b}}$ & $28.0^{\mathrm{c}}$ \\
MM.106 & $77.8^{\mathrm{i}}$ & $91.2^{\mathrm{d}}$ & $84.5^{\mathrm{g}}$ & $71.1^{\mathrm{k}}$ & $54.9^{\mathrm{h}}$ & $63.0^{\mathrm{m}}$ \\
\hline
\end{tabular}

* means in columns marked with the same letter are not significantly different at $\mathrm{P}=0.05$.

In our study, the root system of 'Ligol' apple trees responded very differently to the growing conditions of the pasteurized soil than the above-ground part did. Regardless of the rootstock, the trees grown in the pasteurized soil produced a much larger root system, as determined by the fresh weight of the roots produced, than the trees that 
were grown in the 'sick' soil (Table 5). On average for all of the rootstocks, the trees growing in the pasteurized soil developed a root system 2.27 times larger than those grown in the non-disinfected soil in both years of the study. It can be assumed that if the experiment had lasted longer, or if the trees had been planted in the ground, then those with a much larger root system (from the pasteurized soil) would have grown more vigorously than those grown for a few months in the non-disinfected soil.

Table 5. Weight of the root system of 'Ligol' apple trees grown on different rootstocks in 'sick' soil and disinfected soil (Skierniewice, 2009 and 2010)

\begin{tabular}{lllllll}
\hline \multirow{2}{*}{ Rootstock } & \multicolumn{3}{c}{ 'sick' soil } & \multicolumn{3}{c}{ disinfected soil } \\
\cline { 2 - 7 } & 2009 & 2010 & mean & 2009 & 2010 & mean \\
\hline P 2 & $362^{\mathrm{f} *}$ & $366^{\mathrm{f}}$ & $364^{\mathrm{h}}$ & $786^{\mathrm{f}}$ & $730^{\mathrm{e}}$ & $758^{\mathrm{f}}$ \\
P 14 & $728^{\mathrm{j}}$ & $676^{\mathrm{l}}$ & $702^{\mathrm{k}}$ & $1322^{\mathrm{k}}$ & $1306^{\mathrm{k}}$ & $1314^{\mathrm{m}}$ \\
P 16 & $272^{\mathrm{d}}$ & $248^{\mathrm{d}}$ & $260^{\mathrm{f}}$ & $902^{\mathrm{h}}$ & $870^{\mathrm{g}}$ & $886^{\mathrm{i}}$ \\
P 22 & $340^{\mathrm{e}}$ & $388^{\mathrm{g}}$ & $364^{\mathrm{h}}$ & $738^{\mathrm{e}}$ & $682^{\mathrm{d}}$ & $710^{\mathrm{e}}$ \\
P 59 & $502^{\mathrm{h}}$ & $634^{\mathrm{j}}$ & $568^{\mathrm{j}}$ & $746^{\mathrm{ef}}$ & $846^{\mathrm{f}}$ & $796^{\mathrm{h}}$ \\
P 60 & $426^{\mathrm{g}}$ & $518^{\mathrm{i}}$ & $472^{\mathrm{i}}$ & $632^{\mathrm{d}}$ & $640^{\mathrm{c}}$ & $636^{\mathrm{d}}$ \\
P 66 & $216^{\mathrm{c}}$ & $204^{\mathrm{c}}$ & $210^{\mathrm{d}}$ & $398^{\mathrm{b}}$ & $410^{\mathrm{b}}$ & $404^{\mathrm{b}}$ \\
P 67 & $528^{\mathrm{i}}$ & $424^{\mathrm{h}}$ & $476^{\mathrm{i}}$ & $848^{\mathrm{g}}$ & $724^{\mathrm{e}}$ & $786^{\mathrm{g}}$ \\
P 68 & $212^{\mathrm{c}}$ & $188^{\mathrm{b}}$ & $200^{\mathrm{c}}$ & $480^{\mathrm{c}}$ & $420^{\mathrm{b}}$ & $450^{\mathrm{c}}$ \\
CG 16 & $114^{\mathrm{b}}$ & $106^{\mathrm{a}}$ & $110^{\mathrm{b}}$ & $194^{\mathrm{a}}$ & $162^{\mathrm{a}}$ & $178^{\mathrm{a}}$ \\
M.7 & $334^{\mathrm{e}}$ & $318^{\mathrm{e}}$ & $326^{\mathrm{g}}$ & $1480^{\mathrm{l}}$ & $1436^{\mathrm{l}}$ & $1458^{\mathrm{n}}$ \\
M.9 & $278^{\mathrm{d}}$ & $182^{\mathrm{b}}$ & $230^{\mathrm{e}}$ & $1126^{\mathrm{i}}$ & $1074^{\mathrm{i}}$ & $1100^{\mathrm{k}}$ \\
M.26 & $82^{\mathrm{a}}$ & $106^{\mathrm{a}}$ & $94^{\mathrm{a}}$ & $918^{\mathrm{h}}$ & $910^{\mathrm{h}}$ & $914^{\mathrm{j}}$ \\
MM.106 & $792^{\mathrm{k}}$ & $656^{\mathrm{k}}$ & $724^{\mathrm{l}}$ & $1204^{\mathrm{j}}$ & $1164^{\mathrm{j}}$ & $1184^{1}$ \\
\hline
\end{tabular}

* means in columns marked with the same letter are not significantly different at $\mathrm{P}=0.05$.

Table 6. Chlorophyll content in the leaves of 'Ligol' apple trees grown on different rootstocks in 'sick' soil and disinfected soil (Skierniewice, average for 2009 - 2010)

\begin{tabular}{ccc}
\hline Rootstock & 'sick’ soil & disinfected soil \\
\hline P 2 & $680^{\mathrm{c} *}$ & $627^{\mathrm{b}}$ \\
P 14 & $722^{\mathrm{e}}$ & $644^{\mathrm{e}}$ \\
P 16 & $763^{\mathrm{g}}$ & $638^{\mathrm{d}}$ \\
P 22 & $724^{\mathrm{e}}$ & $649^{\mathrm{e}}$ \\
P 59 & $741^{\mathrm{f}}$ & $638^{\mathrm{d}}$ \\
P 60 & $639^{\mathrm{a}}$ & $588^{\mathrm{a}}$ \\
P 66 & $640^{\mathrm{a}}$ & $591^{\mathrm{a}}$ \\
P 67 & $711^{\mathrm{d}}$ & $701^{\mathrm{g}}$ \\
P 68 & $687^{\mathrm{c}}$ & $659^{\mathrm{f}}$ \\
CG 16 & $704^{\mathrm{d}}$ & $637^{\mathrm{cd}}$ \\
M.7 & $682^{\mathrm{c}}$ & $591^{\mathrm{a}}$ \\
M.9 & $762^{\mathrm{g}}$ & $734^{\mathrm{h}}$ \\
M.26 & $658^{\mathrm{b}}$ & $632^{\mathrm{bc}}$ \\
MM.106 & $706^{\mathrm{d}}$ & $647^{\mathrm{e}}$
\end{tabular}

* means in columns marked with the same letter are not significantly different $\mathrm{Pt}=0.05$.

Chlorophyll content in the leaves of 'Ligol' apple trees was higher in trees grown in the 'sick' soil than in those cultivated in pasteurized soil (Table 6). Undoubtedly, it was associated with higher vigor of trees growing in the “sick' soil. The highest chlorophyll content for this cultivar in the 'sick' soil was observed when trees were 
cultivated on P 16 and M.9 rootstocks, and the lowest chlorophyll content was noted when the apple trees were grown on P 60 and P 66 rootstocks.

\section{Conclusions}

Pasteurization of the soil contributed to a slight increase in soil $\mathrm{pH}$ and a marked increase in the levels of $\mathrm{P}, \mathrm{K}$ and $\mathrm{Mg}$ in the soil. Leaves of the trees grown in the pasteurized soil contained larger amounts of macroelements (N, P, $\mathrm{K}, \mathrm{Mg}$ and $\mathrm{Ca}$ ) than the leaves of the trees grown in the 'sick' soil. Trees on vigorous rootstocks grew more vigorously than those on poorly growing rootstocks regardless of whether the soil had been pasteurized or not. However, all the 'Ligol' apple trees growing in the pasteurized soil produced a much larger root system than those growing in the 'sick' soil. From several rootstocks studied in the experiment we recommend two English rootstocks M.9 (dwarf) and M.26 (semi-dwarf) and three Polish rootstocks - P 60 (semi-dwarf), P 67 (dwarf to semi-dwarf) and P 14 (semi-dwarf) to growers from Poland.

\section{Acknowledgements}

The investigation was partially sponsored by the Ministry of Science and Higher Education (project No. 376/N-COST/T2009/0).

\section{References}

Buszard, D. J., \& Jensen, P. (1986). A note on the incidence of apple replant disease in Quebec Canada orchards. Phytoprotection, 67, 133-136.

Facteau, T. J., Cestnut, N. E., \& Rowe, K. E. (1996). Tree, fruit size and yield of 'Bing' sweet cherry as influenced by rootstock, replant area, and training system. Scientia Horticulturae Amsterdam, 67, 13-26. http://dx.doi.org/10.1016/S0304-4238(96)00943-0

Kłossowski, W., \& Czynczyk, A. (1974). Analizy chemiczne gleby i liści jako metody badań potrzeb nawozowych jabłoni w szkółce. Pr. Inst. Sad., XVIII, 61-76.

Laurent, A. S., Merwin, I. A., Fazio, G., Thies, J. E., \& Brown, M. G. (2010). Rootstock genotype succession influences apple replant disease and root-zone microbial community composition in an orchard soil. Plant and Soil, 337(1), 259-272. http://dx.doi.org/10.1007/s11104-010-0522-z

Leinfelder, M., \& Merwin, I. A. (2006). Rootstock selection, pre-plant soil treatments, and tree planting positions as factors in managing apple replant disease. HortScience, 41, 394-401.

Mai, W. F., \& Abawi, G. S. (1981). Controlling replant diseases of pome and stone fruits in Northeastern United States by replant fumigation. Plant Disease, 65, 859-864.

Mai, W. F., Merwin, I. A., \& Abawi, G. S. (1994). Diagnosis, etiology, and management of replant problems in New York cherry and apple orchards. Acta Horticulturae, 363, 33-41.

Mazzola, M. (1998). Elucidation of the microbial complex having a causal role in the development of apple replant disease in Washington. Phytopathology, 88, 930-938. http://dx.doi.org/10.1094/PHYTO.1998.88.9.930

Otto, G., \& Winkler, H. (1993). Soil fumigation for controlling replant problems in apple orchards. Acta Horticulturae, 324, 91-96.

Smith, T. (1994). Successful management of orchard replant disease in Washington. Horticulturae, 363, 161-168.

Szczygiel, A., \& Zepp, A. L. (1998). An occurrence and importance of apple replant disease in Polish orchards. Acta Horticulturae, 477, 99-102.

Vang-Petersen, O. (1970). Apple trees on tree-sick soil. Tidsskrift for Planteavl, 74, 490-496.

\section{Copyrights}

Copyright for this article is retained by the author(s), with first publication rights granted to the journal.

This is an open-access article distributed under the terms and conditions of the Creative Commons Attribution license (http://creativecommons.org/licenses/by/3.0/). 